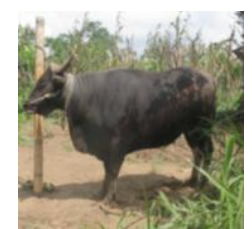

Jurnal FADET UNUD

\title{
KUALITAS TELUR AYAM ISA BROWN UMUR 100-104 MINGGU YANG DIBERI RANSUM KOMERSIAL DENGAN TAMBAHAN TEPUNG KULIT KERANG
}

\author{
Aziz F., G. A. M. K. Dewi, dan M. Wirapartha \\ P S Sarjana Peternakan, Fakultas Peternakan, Universitas Udayana, Denpasar, Bali \\ E-mail: azizfathani@ student.unud.ac.id_Hp:+6283115938589
}

\begin{abstract}
ABSTRAK
Penelitian ini bertujuan untuk mengetahui kualitas telur ayam Isa Brown umur 100-104 minggu yang diberi ransum komersial dengan tambahan tepung kulit kerang. Penelitian dilaksanakan di Desa Pesedahan, Kecamatan Manggis, Karangasem, Bali, dan berlangsung selama 4 minggu. Rancangan yang digunakan adalah Rancangan Acak Lengkap (RAL) dengan 4 perlakuan dan 5 ulangan, dan setiap ulangan menggunakan 5 ekor ayam. Perlakuan yang diberikan yaitu; ransum komersial tanpa tambahan tepung kulit kerang (A), ransum komersial dengan tambahan $1 \%$ tepung kulit kerang (B), ransum komersial dengan tambahan 2\% tepung kulit kerang (C), ransum komersial dengan tambahan 3\% tepung kulit kerang (D).Variabel yang diamati adalah berat telur, indeks telur, berat kerabang telur, tebal kulit telur, Haugh Unit, pH telur, dan warna kuning telur. Hasil penelitian ini menunjukkan bahwa pemberian ransum komersial dengan tambahan tepung kulit kerang 1\%, 2\%, dan 3\% memberikan hasil yang secara statistik tidak berbeda nyata $(\mathrm{P}>0,05)$ terhadap berat telur, indeks telur, berat kerabang telur, tebal kulit telur, Haugh Unit, $\mathrm{pH}$ telur dan warna kuning telur dibandingkan dengan perlakuan kontrol (A). Berdasarkan hasil penelitian ini dapat disimpulkan bahwa pemberian tepung kulit kerang dengan 1\%, $2 \%$ dan $3 \%$ pada ayam Isa Brown umur 100-104 minggu tidak berpengaruh terhadap kualitas telur yang meliputi berat telur, indeks telur, berat kerabang telur, tebal kulit telur, Haugh Unit, $\mathrm{pH}$ telur dan warna kuning telur serta belum mampu meningkatkan kualitas telur pada warna kuning telur sedangkan kualitas telur pada berat telur, indeks telur, berat kerabang, tebal kulit telur, Haugh Unit, dan $\mathrm{pH}$ masih memiliki kualitas yang baik.
\end{abstract}

Kata kunci : kualitas telur, tepung kulit kerang, isa brown

\section{THE QUALITY OF ISA BROWN CHICKEN EGGS AGED 100-104 WEEKS GIVEN COMMERCIAL RATIONS WITH ADDITIONAL SEASHELL FLOUR}

\begin{abstract}
This study aims to determine the quality of Isa Brown chicken eggs aged 100-104 weeks which were given commercial rations with additional seashell flour. The study was conducted in Pesedahan Village, Manggis District, Karangasem, Bali, and lasts for 4 weeks.
\end{abstract}


The design used was a Completely Randomized Design (CRD) with 4 treatments and 5 replications, and each test used 5 chickens. The treatment given is; commercial rations without the addition of seashell flour (A), commercial rations with an additional $1 \%$ of seashell flour (B), commercial rations with an additional $2 \%$ of seashell flour (C), commercial ration with an addition of $3 \%$ seashell flour (D). The variables observed were egg weight, egg index, egg shell weight, egg shell thickness, Haugh Unit, egg $\mathrm{pH}$, and egg yolk color. The results of this study indicate that the provision of commercial rations with the addition of $1 \%$, $2 \%$ and $3 \%$ seashell gives statistically not significantly different results $(\mathrm{P}>0.05)$ on egg weight, egg index, egg shell weight, shell thickness eggs, Haugh Unit, egg pH and egg yolk color compared with the control treatment (A). Based on the results of this study it can be concluded that the administration of seashell flour with 1\%,2\% and 3\% in Isa Brown chicken aged 100-104 weeks has no effect on egg quality which includes egg weight, egg index, egg shell weight, egg shell thickness, Haugh Unit, egg $\mathrm{pH}$ and egg yolk color and have not been able to improve egg quality in egg yolk while egg quality in egg weight, egg index, eggshell weight, egg shell thickness, Haugh Unit, and pH still have good quality.

keywords: egg quality, seashell flour, isa brown

\section{PENDAHULUAN}

Telur merupakan salah satu sumber protein hewani yang memiliki rasa enak, mudah dicerna dan bergizi tinggi sehingga digemari banyak orang. Selain itu telur mudah diperoleh dan harganya terjangkau. Masyarakat umumnya mencukupi kebutuhan protein dengan mengkonsumsi telur. Begitu besarnya manfaat telur dalam kehidupan manusia sehingga telur sangat dianjurkan untuk dikonsumsi anak-anak yang sedang dalam masa pertumbuhan, ibu hamil dan menyusui, orang yang sedang sakit atau dalam proses penyembuhan, serta usia lanjut. Telur yang dikonsumsi oleh masyarakat Indonesia umumnya berasal dari unggas yang diternakkan. Jenis telur yang banyak dikonsumsi adalah telur ayam, telur puyuh dan telur bebek. Telur ayam lebih banyak digunakan dalam kehidupan sehari-hari karena mudah diolah dan dimanfaatkan untuk kebutuhan manusia seperti sebagai bahan pencampur makanan, dan sebagainya. Telur ayam mempunyai bentuk fisik bulat sampai lonjong dengan ukuran yang berbeda-beda, tergantung jenis hewan, umur dan sifat genetiknya. Telur tersusun atas tiga bagian yaitu kulit telur, putih telur dan kuning telur (Winarno, 2002).

Dengan melihat aspek tingkat konsumsi masyarakat terhadap telur sangat tinggi maka perlu adanya telur yang mempunyai kualitas yang baik. Menurut Wahju (1997), kualitas telur meliputi kualitas kulit telur, derajat kekentalan atau kualitas albumen, kualitas atau nilai gizi yang ditujukan untuk kepentingan konsumen, bebas kerusakan-kerusakan misalnya bintik darah dan kualitas kuning telur. Faktor-faktor yang mempengarui kualitas telur tersebut diantaranya adalah kandungan ransum atau zat makanan untuk umur ayam >18 minggu 
(layer) membutuhkan energi 2.850,00 $\mathrm{Kkal} / \mathrm{kg}$, protein $16,00 \%$, lemak 1,00\%, kalsium 1,80\%, phosphor 0,35\%, NRC, (1994) dan SNI (2008), penyakit, temperatur, genetik dan umur ayam. Faktor lain yang mempengaruhi kualitas telur adalah lama dan suhu penyimpanan (Sudaryani, 2003).

Peternakan ayam petelur biasanya menggunakan ransum komersial dalam pemeliharaan, hal itu karena ransum komersial lebih efisien, tidak rumit dan lebih jelas dalam hal kandungan nutrisi. Ayam Isa Brown memiliki periode bertelur antara 18-80 minggu, puncak produksi sebesar 95\% pada umur 26 minggu (Hendrix, 2006). Ayam Isa Brown diafkir pada umur 80 minggu karena semakin bertambahnya umur ayam maka telur yang dihasilkan akan mengalami penurunan kualitas, diakibatkan umur menurunkan kemampuan penceranaan dan metabolisme tubuh ayam sehingga kandungan mineral dalam tubuh ayam semakin berkurang (Hargitai et al., 2011), namun banyak peternak ingin mempertahankan ayam yang sudah berumur 80 minggu keatas dengan dalih day old chiken mahal dengan ratarata han-day production $63 \%$ dan lamanya masa pemeliharaan dari day old chiken sampai ayam bertelur menjadikan peternak berfikir kembali. Maka dari itu untuk mengatasi kekurangan mineral pada tubuh ayam saat masa afkir pemeliharaan, perlu penambahan kalsium yang cukup kedalam ransum (Sumadi, 2017). Dalam hal ini solusi yang digunakan adalah kalsium yang bersumber dari tepung kulit kerang. Menurut Kurniasih et al. (2017) kandungan tepung kulit kerang mempunyai $40 \%$ kalsium $1 \%$ fosfor dan $4 \%$ protein. Sebelumnya Dewi (2010) meneliti bahwa tambahan kalsium 1\% pada ransum sudah berpengaruh nyata terhadap kualitas telur. Berdasarkan uraian diatas maka perlu dilakukan penelitian kualitas telur ayam Isa Brown umur 100-104 minggu yang diberi ransum komersial dengan tambahan 1\%, 2\% dan 3\% tepung kulit kerang sebagai sumber kalsiumnya.

\section{MATERI DAN METODE}

\section{Ayam petelur}

Penelitian ini menggunakan ayam petelur Isa Brown umur 100 minggu sebanyak 100 ekor, dengan bobot badan ayam rata-rata $\pm 1,650$ gr.

\section{Tempat dan lama penelitian}

Penelitian ini dilaksanakan di Desa Pesedahan, Kecamatan Manggis, Kabupaten Karangasem, dan Laboratorium Ternak Unggas Fakultas Peternakan Universitas Udayana, dan berlangsung selama 4 minggu. 


\section{Kandang dan perlengkapan}

Kandang yang digunakan dalam penelitian ini yaitu kandang panggung dengan penunjang dibawah pondasi beton dan atap dari seng, jenis kandang sistem battery dengan panjang 1 unitnya $100 \mathrm{~cm}$ dalam 1 unit berisikan 5 petak kandang dengan masing masing petak kandang berukuran 20 × $35 \mathrm{~cm}$, didepan petak kandang ditempatkan tempat pakan, dan tempat air minum.

\section{Peralatan laboratorium}

Alat yang digunakan di laboratorium ialah timbangan elektrik/roti, egg tray, egg multitester, $\mathrm{pH}$ meter, micrometer sekrup, tissu peralatan analisis laboratorium serta alat tulis kantor (ATK) untuk keperluan pencatatan dan dokementasi kegiatan.

\section{Komposisi dan kandungan nutrisi ransum penelitian}

Ransum yang digunakan dalam penelitian ini adalah ransum komersial KLS Super Plus yang diproduksi oleh PT Wonokoyo dan dengan tambahan tepung kulit kerang. Komposisi ransum ayam petelur dapat dilihat pada Tabel 1.

Tabel 1. Komposisi ransum penelitian

\begin{tabular}{ccccc}
\hline \multirow{2}{*}{ Ransum } & \multicolumn{5}{c}{ Perlakuan $^{\text {1) }}$} \\
\cline { 2 - 5 } & $\mathrm{A}^{2)}$ & $\mathrm{B}$ & $\mathrm{C}$ & $\mathrm{D}$ \\
\hline Ransum komersial & 100 & 99 & 98 & 97 \\
Tepung kulit kerang (\%) & 0 & 1 & 2 & 3 \\
Total & 100 & 100 & 100 & 100 \\
\hline
\end{tabular}

Keterangan :

1. Ransum komersial KLS Super Plus produksi PT Wonokoyo

2. $\mathrm{A}=$ Ransum komersial tanpa tambahan tepung kulit kerang, $\mathrm{B}=$ ransum komersial dengan tambahan $1 \%$ tepung kulit kerang, $\mathrm{C}=$ ransum komersial dengan tambahan $2 \%$ tepung kulit kerang, (D) ransum komersial dengan tambahan $3 \%$ tepung kulit kerang. 
Tabel 2. Kandungan nutrisi ransum penelitian

\begin{tabular}{lccccc}
\hline \multicolumn{1}{c}{ Kandungan nutrisi Ransum komersial } & \multicolumn{5}{c}{ Perlakuan ${ }^{\mathrm{I}}$ ) } \\
\cline { 2 - 6 } & $\mathrm{A}$. kulit kerang & $\mathrm{B}$ & $\mathrm{C}$ & $\mathrm{D}$ & Standar $^{2)}$ \\
\hline Energi Termetabolis Kkal/Kg & 2900 & 2871 & 2842 & 2813 & $2900-3000$ \\
Protein Kasar (\%) & 18,00 & 17,86 & 17,72 & 17,58 & $17-20$ \\
Lemak Kasar (\%) & 10,13 & 10,03 & 9,93 & 9,83 & $4-11$ \\
Serat Kasar (\%) & 3,08 & 3,05 & 3,02 & 2,99 & $3-8$ \\
Kalsium (\%) & 3,13 & 3,50 & 3,87 & 4,24 & $3,00-4,5$ \\
Phosfor P (\%) & 0,45 & 0,46 & 0,46 & 0,47 & $0,45-1,5$ \\
\hline
\end{tabular}

Keterangan :

1) $\mathrm{A}=$ ransum komersial tanpa tambahan tepung kulit kerang

$\mathrm{B}=$ ransum komersial dengan tambahan $1 \%$ tepung kulit kerang

$\mathrm{C}=$ ransum komersial dengan tambahan $2 \%$ tepung kulit kerang

$\mathrm{D}=$ ransum komersial dengan tambahan $3 \%$ tepung kulit kerang

2) Standart Scott et al. (1982)

3) Ransum komersial KLS Super Plus PT Wonokoyo

\section{Rancangan penelitian}

Penelitian ini dilakukan dengan menggunakan Rancangan Acak Lengkap (RAL) dengan 4 perlakuan dan 5 ulangan, dimana tiap ulangan terdiri dari 5 ekor ayam petelur umur 100 minggu. Total ayam yang digunakan 100 ekor. Perlakuan yang diberikan yaitu:

$\mathrm{A}=$ Ransum komersial tanpa tambahan tepung kulit kerang.

$\mathrm{B}=$ Ransum komersial dengan tambahan $1 \%$ tepung kulit kerang.

$\mathrm{C}=$ Ransum komersial dengan tambahan $2 \%$ tepung kulit kerang.

$\mathrm{D}=$ Ransum komersial dengan tambahan 3\% tepung kulit kerang.

\section{Pemberian ransum}

Pemberian ransum pada ternak ayam petelur dilakukan dengan cara ad libitum mulai dari pagi hari (jam 08.00 wita) sampai keesokan harinya (jam 08.00 wita). ransum diberikan dengan menempatkan langsung ransum ke tempat pakan didepan kandang pada setiap unit perlakuan.

\section{Teknik pengambilan data}

Proses pengambilan data dilakukan setiap hari selama penelitian berlangsung sesuai perlakuan dan ulangan. Telur dikumpulkan pada tiap ulangan dan dicari rata-rata berat telur, kemudian diambil 1 butir yang mendekati rata-rata pada masing-masing ulangan ditiap perlakuan, dan akan diuji kualitasnya di Laboratorium Ternak Unggas Fakultas Peternakan Universitas Udayana. 


\section{Variabel yang diamati}

Variabel yang diamati dalam penelitian ini yaitu:

a. Berat telur: Berat telur didapat dengan cara menimbang telur tersebut.

b. Indeks telur: Perbandingan antara lebar dan panjang telur itu sendiri. Menurut Suhardi (2013) pengukuran indeks telur dapat dihitung dengan: rumus Indeks telur $\frac{\text { lebar telur }}{\text { panjang telur }} \times 100 \%$

c. Berat kerabang telur: Telur dipecah lalu kerabang telur di timbang atau hasil dari pengurangan bobot telur dikurangi putih dan kuning telur.

d. Tebal kulit telur: Tebal kulit telur didapat dengan cara mengukur menggunakan alat micrometer.

e. Haugh Unit: Haugh Unit diukur menggunakan peralatan laboratorium egg multitester. Menurut Panda (1996) Haugh Unit diukur dengan pengukuran tinggi albumen dan bobot telur, yaitu :

$H U=100 \log \left(H+7,57-1,7 W^{0,37}\right)$

\section{Keterangan: $\quad \mathrm{HU}$ : Haugh Unit \\ $\mathrm{H} \quad$ : Tinggi putih telur \\ W : Bobot telur (g)}

f. $\mathrm{pH}$ : $\mathrm{pH}$ telur diukur dengan cara memecah telur lalu ditaruh didalam wadah dan kemudian menggunakan $\mathrm{pH}$ meter untuk mengukur tingkat $\mathrm{pH}$.

g. Warna kuning telur: Warna kuning telur dapat dinilai dengan melihat secara langsung/visual dan memberi skor warna kuning dengan menggunakan yolk colour fan.

\section{Analisis Data}

Data yang diperoleh dari hasil penelitian ini dianalisis dengan menggunakan analisis sidik ragam (Anova) dan apabila terdapat perbedaan yang nyata antar perlakuan $(\mathrm{P}<0,05)$, maka dilanjutkan dengan Uji Jarak Berganda Duncan (Steel dan Torrie 1989).

\section{HASIL DAN PEMBAHASAN}

Hasil peneltian kualitas telur ayam Isa Brown umur 100-104 minggu yang diberi tepung kulit kerang dalam ransum komersial yang meliputi; berat telur, indeks telur, berat kerabang telur, tebal kulit telur, Haugh Unit, $\mathrm{pH}$ telur, dan warna kuning telur dapat dilihat pada Tabel 3. 
Tabel 3. Kualitas telur ayam Isa Brown umur 100-104 minggu yang diberi ransum komersial dengan tambahan tepung kulit kerang

\begin{tabular}{lccccc}
\hline \multirow{2}{*}{ Variabel } & \multicolumn{4}{c}{ Perlakuan $^{\mathrm{I}}$} & \multirow{2}{*}{ SEM $^{2)}$} \\
\cline { 2 - 5 } & $\mathrm{A}$ & $\mathrm{B}$ & $\mathrm{C}$ & $\mathrm{D}$ & \\
\hline Berat telur (g) & $63,32^{\mathrm{a} 3)}$ & $63,82^{\mathrm{a}}$ & $63,52^{\mathrm{a}}$ & $63,04^{\mathrm{a}}$ & 0,30 \\
Indeks telur (\%) & $78,47^{\mathrm{a}}$ & $78,29^{\mathrm{a}}$ & $78,38^{\mathrm{a}}$ & $78,21^{\mathrm{a}}$ & 0,44 \\
Berat kerabang (g) & $7,66^{\mathrm{a}}$ & $8,64^{\mathrm{a}}$ & $8,60^{\mathrm{a}}$ & $8,08^{\mathrm{a}}$ & 0,14 \\
Tebal kulit telur (mm) & $0,39^{\mathrm{a}}$ & $0,42^{\mathrm{a}}$ & $0,42^{\mathrm{a}}$ & $0,43^{\mathrm{a}}$ & 0,0035 \\
Haugh unit & $78,99^{\mathrm{a}}$ & $79,59^{\mathrm{a}}$ & $80,63^{\mathrm{a}}$ & $80,36^{\mathrm{a}}$ & 0,48 \\
Ph & $7,60^{\mathrm{a}}$ & $7,40^{\mathrm{a}}$ & $7,20^{\mathrm{a}}$ & $8,60^{\mathrm{a}}$ & 0,18 \\
Warna Kuning & $7,20^{\mathrm{a}}$ & $6,80^{\mathrm{a}}$ & $7,00^{\mathrm{a}}$ & $7,20^{\mathrm{a}}$ & 0,18 \\
\hline
\end{tabular}

Keterangan :

1) A : Pemberian ransum komersial tanpa tambahan tepung kulit kerang

B : Pemberian ransum komersial dengan tambahan $1 \%$ tepung kulit kerang

$\mathrm{C}$ : Pemberian ransum komersial dengan tambahan $2 \%$ tepung kulit kerang

$\mathrm{D}:$ Pemberian ransum komersial dengan tambahan $3 \%$ tepung kulit kerang

2) SEM (Standart error of the treatment means)

3) Nilai dengan huruf yang sama pada baris yang sama menunjukkan tidak berbeda nyata $(\mathrm{P}>0.05)$.

Berat telur yang diperoleh pada penambahan tepung kulit kerang 1\%, 2\%, dan 3\% pada perlakuan (B), (C), dan (D) menunjukkan hasil tidak berbeda nyata $(\mathrm{P}>0,05)$ dibandingkan dengan berat telur ayam pada perlakuan kontrol (A). Hal ini dipengaruhi oleh umur ayam yang sudah tua pada ayam Isa Brown yang menyebabkan fungsi fisiologis dari organ-organ dalam tubuh ayam menurun sehingga penyerapan tidak optimal. Hal ini diutarakan oleh Hafez (2000) yang menyatakan produksi dan kualitas telur pada tahun-tahun berikutnya cenderung akan terus menurun seiring semakin tua umur ayam. Nakajima (1990) menyatakan penambahan kalsium sesuai dengan kebutuhan ayam petelur dapat menghasilkan bobot yang optimal. Kalsium yang dicerna baik oleh ayam akan menghasilkan telur yang bobotnya lebih besar (Dewi, 2010). Pada perlakuan (D) penambahan tepung kulit kerang 3\% lebih rendah $0.4 \%$ dari perlakuan kontrol (A) hal ini dikarenakan kalsium pada ransum memiliki jumlah yang lebih besar dari perlakuan lain maka menyebabkan palatabilitas menjadi rendah sesuai dengan pernyatan yang dikemukakan oleh Anggorodi (1995) bila kandungan kalsium dalam pakan berlebihan akan menyebabkan menurunnya konsumsi pakan akibat keterbatasan fisiologis yang mempengaruhi selera makan atas kalsium, sesuai data rujukan konsumsi ransum menunjukkan pada pemberian ransum dengan tambahan $1 \%$ tepung kulit kerang (B) meningkatkan konsumsi ransum $0,02 \%$ dibandingkan perlakuan kontrol (A) dan pemberian 
ransum komersial dengan tambahan tepung kulit kerang 2\%(C), dan 3\% (D) masing-masing 0,76\%, dan 0,96\% menurun dibandingkan perlakuan kontrol (A). Hal ini disebabkan karena faktor umur ayam yang sudah tua seperti yang disebutkan oleh Campbell et al.,(2003) faktor yang mempengaruhi berat telur yaitu genetik, umur, besar ayam, tahap produksi dan nutrsi. Ayam yang sudah tua metabolisme tubuh akan semakin menurun sehingga penyerapan kalsium akan semakin lambat di dalam tubuh sehingga penambahan kalsium setidaknya dapat meningkatkan sedikit dari berat telur.

Indeks telur yang diperoleh pada penambahan tepung kulit kerang 1\%, 2\% dan 3\% pada perlakuan (B), (C) dan (D) menunjukkan hasil tidak berbeda nyata $(\mathrm{P}>0,05) 0,23 \%, 0,12 \%$, dan $0,33 \%$ lebih rendah dibandingkan perlakuan kontrol (A). Hal ini dipengaruhi oleh umur, periode produksi dan pakan, sesuai dengan Darmawanti et al., (2016) yang menyatakan bahwa indeks bentuk telur dipengaruhi oleh faktor genetik, umur induk, periode produksi, umur dewasa kelamin, saluran reproduksi dan kualitas pakan. Pada ayam umur yang tua atau masuk periode akhir/afkir memiliki berat telur dan indeks yang bervariasi karena kemampuan penyerapan zat makanan yang sudah menurun membuat indeks dan besar kecilnya telur beragam. Periode awal indeks bentuk telur akan terlihat kecil dan masuk akhir periode bertelur indeks bentuk telur terlihat lebih besar. Pembentukan telur akan meningkatkan bentuk dan beratnya selama periode produksi sementara ketebalan dan kekuatan kulit telur biasanya menurun. Kekuatan dan ketebalan cangkang sangat berkorelasi satu sama lain. Bentuk indeks memiliki pengaruh terhadap proporsi albumen dan yolk. Duman et al., (2016) menyatakan bahwa telur dengan karakteristik seperti indeks bentuk dan ketebalan cangkang mempengaruhi risiko telur yang retak. Kesiapan saluran reproduksi mempengaruhi hasil indeks bentukan telur lonjong, normal dan bulat. Indeks bentuk telur dipengaruhi oleh saluran reproduksi dan dapat berkembang karena adanya perubahan pada daerah magnum, istmus dan uterus (organ pembentukan telur).

Berat kerabang telur pada penambahan tepung kulit kerang dalam ransum komersial $1 \%, 2 \%$ dan $3 \%$ pada perlakuan (B), (C), dan (D) menunjukkan peningkatan $12,79 \%, 12,27 \%$ dan 5,48\% lebih tinggi tidak berbeda nyata $(\mathrm{P}>0,05)$ dari perlakuan kontrol $(\mathrm{A})$. Hal ini dipengaruhi juga dengan ketebalan kulit telur, karena berat kerabang telur berhubungan dengan tebal kulit telur, semakin tebal kulit telur maka berat kerabang telur juga akan mempunyai nilai yang meningkat (Cooper and Jhonston, 1974). Pada penelitian ini tebal kulit telur yang diberi tambahan tepung kulit kerang dalam ransum komersial 1\%, 2\%, dan 3\% pada perlakuan (B), (C), dan (D) mempunyai nilai 5,58\%, 6,09\% dan 8,12\% lebih tinggi tidak 
berbeda nyata $(\mathrm{P}>0,05)$ dibandingkan perlakuan kontrol (A). Meningkatnya berat kerabang telur dan tebal kulit telur dengan ditambahkannya tepung kulit kerang juga dipengaruhi oleh penyerapan kalsium di usus halus, ketika kalsium diserap baik diusus halus maka berat dan tebal kulit yang didapat mengalami peningkatan kualitas dalam pembentukan kerabang telur pada bagian uterus. Hal ini dikemukakan Oderkirk (2001) konsumsi kalsium $40 \%$ dapat diserap oleh usus halus bila proses pembentukan telur tidak sedang berlangsung tapi sebaliknya bila sedang terjadi proses pembentukan kerabang maka kalsium dapat diserap sampai $72 \%$, ini menjadikan bahwa kalsium yang ada pada tepung kulit kerang dapat diserap hingga $72 \%$ dan dapat meningkatkan nilai berat kerabang dan tebal kulit telur. Menurut Steward and Abbott (1972) standart tebal kulit telur berkisar antara 0,33-0,35mm, dan rataan kulit telur pada penelitian ini tergolong baik yaitu berkisar 0,39-0,43mm.

Haugh Unit telur ayam Isa Brown pada penambahan tepung kulit kerang dalam ransum komersial 1\%, 2\% dan 3\% pada perlakuan (B), (C), dan (D) menunjukkan nilai Haugh Unit yang lebih tinggi dari pada perlakuan kontrol (A) secara statistik tidak berbeda nyata $(\mathrm{P}>0,05)$. Hal ini terjadi karena putih telur berkorelasi positif terhadap nilai $H U$. Semakin tinggi putih telur, maka semakin tinggi nilai $H U$, semakin bagus kualitas telur tersebut dan menunjukkan juga bahwa telur masih baru dan segar (Tugiyanti dan Iriyanti, 2012). Hal ini diperkuat oleh Andi (2013) menyatakan bahwa nilai haugh unit dipengaruhi oleh kandungan ovomusin yang terdapat pada putih telur, apabila putih telur semakin tinggi maka nilai haugh unit yang diperoleh semakin tinggi pula nilai haugh unit pada penelitian ini mempunyai nilai 80,63 pada perlakuan (C) dengan peningkatan 2,08\% dari kontrol (A) dengan konsumsi ransum terendah dari perlakuan lain yakni 116,800gr per hari. Putih telur yang mengandung ovomusin lebih sedikit maka akan lebih cepat mencair. Berat telur meningkat maka volume putih telur yang ada didalam telur akan bertambah dan jika rongga pada kulit telur besar maka akan menyebabkan penurunan kualitas $H U$ baik disebabkan oleh kontaminasi mikroba kerusakan fisik dan juga penguapan. Hal ini diperkuat oleh Haryono (2000) kulit telur yang tipis relatif berpori lebih banyak dan besar, sehingga mempercepat turunnya nilai Haugh Unit yang terjadi akibat penguapan. $\mathrm{CO}^{2}$ yang hilang melalui pori kerabang telur mengakibatkan konsentrasi ion bikarbonat dalam putih telur menurun dan merusak sistem buffer. Hal tersebut menjadikan $\mathrm{pH}$ naik dan putih telur bersifat basa yang diikuti dengan kerusakan serabut serabut ovomusin (yang memberikan tekstur kental), sehingga kekentalan putih telur menurun. (Jazil et al., 2013). Haugh Unit pada penelitian ini sudah memberikan hasil yang baik karena mencapai pada nilai rata-rata $H U 79.89$ yang dimana sesuai dengan teori nilai 
Haugh Unit lebih dari 72 dikategorikan sebagai telur berkualitas AA, nilai Haugh Unit 60-72 sebagai telur berkualitas A, nilai Haugh Unit 31-60 sebagai telur berkualitas B dan nilai Haugh Unit kurang dari 31 dikategorikan sebagai telur berkualitas C (USDA, 2000).

$\mathrm{pH}$ telur pada penambahan tepung kulit kerang dalam ransum komersial $1 \%$, dan $2 \%$, pada perlakuan (B), dan (C) memiliki pH 7,4 dan 7,2 lebih rendah $2.7 \%$ dan 5,6\% tidak berbeda nyata $(\mathrm{P}>0,05)$ dibandingkan perlakuan (A) yaitu 7.6. Nilai perlakuan (B) dan (C) lebih baik dari pada $\mathrm{pH}$ pada perlakuan (D) yaitu meningkat $13.2 \%$. Hal ini sesuai dengan penelitian Kunaifi et al., (2019) telur segar yang disimpan 0-14 hari memiliki kondisi pH 7 karena belum memberikan peluang terhadap mikroba untuk merombak protein maupun lemak pada telur, sehingga tidak terjadi kerusakan telur oleh mikroba. Penambahan tepung kulit kerang ini nilai rata-rata $\mathrm{pH}$ telur berada diatas 7 atau netral, yang berarti bahwa ayam yang sudah tua diberikan tambahan kalsium dari tepung kulit kerang tidak mempengaruhi $\mathrm{pH}$ pada telur ayam itu sendiri. pH tertinggi pada penelitian ini terdapat pada perlakuan (D) dan jika telur mengalami kenaikan $\mathrm{pH}$ maka akan mengakibatkan telur menjadi semakin encer (Djaelani, 2016).

Warna kuning telur ayam Isa Brown menunjukkan pada pemberian tepung kulit kerang dalam ransum komersial $1 \%$ dan $2 \%$ pada perlakuan (B) dan (C) tidak berbeda nyata $(\mathrm{P}>0,05)$ dibandingkan perlakuan kontrol (A) dan perlakuan (D) yang mempunyai nilai sama 7,2. Hal ini dikarenakan bahwa penambahan tepung kulit kerang tidak memberi banyak pengaruh terhadap kuning telur yang dimana kandungan tepung kulit kerang hanya kaya akan kalsium tidak mengandung zat warna xantofil dalam golongan hidrosi-karotenoid. juga disebutkan bahwa semakin kuning warna kuning telur maka semakin banyak kuning telur mengandung zat warna xantofil. Seperti pernyataan Amrullah (2003) warna kuning telur dipengaruhi oleh zat warna xantofil yang banyak terdapat dalam golongan hidrosi-karotenoid, dan juga disebabkan dengan adanya hubungan antara kandungan nutrien ransum yang hampir sama pada setiap perlakuan (Ardika et al., 2017). Zat tersebut selain mempengaruhi warna kuning, shank, paruh, pigmen ini akan disimpan di dalam kuning telur. Pada penelitian ini skor yang didapat dari warna kuning telur yaitu dengan rata-rata 7.05, warna kuning telur berpengaruh pada selera konsumen, umumnya yang lebih disukai berkisar dari kuning emas sampai dengan orange, dengan skor kuning telur lebih dari 7 (Chung, 2002). Sudaryani (2003) menyatakan bahwa skor warna kuning telur yang baik berkisar 9-12. Semakin tinggi warna kuning telur makan semakin baik kualitas telur tersebut (Muharlien, 2010). 


\section{SIMPULAN DAN SARAN}

\section{Simpulan}

Berdasarkan hasil penelitian ini dapat disimpulkan bahwa: (1) Pemberian ransum komersial dengan tambahan 1\%,2\%, dan 3\% tepung kulit kerang pada ayam Isa Brown umur 100-104 minggu tidak berpengaruh terhadap kualitas telur yang meliputi berat telur; indeks telur, berat kerabang, tebal kulit telur, Haugh Unit, pH, dan warna kuning telur; Pemberian ransum komersial dengan tambahan 1\%, 2\%, dan 3\% tepung kulit kerang pada ayam umur 100-104 minggu belum mampu meningkatkan kualitas telur pada warna kuning telur sedangkan kualitas telur pada berat telur, indeks telur, berat kerabang, tebal kulit telur, Haugh Unit, dan pH masih memiliki kualitas yang baik.

\section{Saran}

Dari penelitian ini dapat disarankan kepada peternak ayam Isa Brown bahwa pemberian ransum komersial KLS Super Plus PT Wonokoyo sudah cukup diberikan pada ayam Isa Brown umur 100-104 minggu karena sudah mengandung kalsium 3,13\% pada ransumnya tanpa harus diberkan penambahan 1\%,2\%, dan 3\% pada ransum KLS Super Plus produksi PT Wonokoyo, juga perlu untuk dilakukan penelitian lebih lanjut dengan level tepung kulit kerang dan dengan kandungan nutrisi (xantofil) ransum yang lebih tinggi untuk kualitas kuning telur yang baik pada ayam Isa Brown umur 100-104 minggu.

\section{UCAPAN TERIMAKASIH}

Penulis mengucapkan terimakasih yang sebesar-besarnya kepada Rektor Universitas Udayana Prof. Dr. dr. A. A. Raka Sudewi, Sp. S (K), Dekan Fakultas Peternakan Dr. Ir. I Nyoman Tirta Ariana, MS. dan seluruh elemen yang telah bekerja, membantu dan meluangkan waktunya selama penelitian hingga diterbitkannya jurnal ini. Terimakasih juga penulis sampaikan kepada pihak-pihak yang telah mendukung memberi semangat dan dorongan sehingga bisa menyelesaikan penelitian ini dengan baik dan lancar.

\section{DAFTAR PUSTAKA}

Amrullah, I. K. 2003. Nutrisi Ayam Petelur. Lembaga Satu Gunung Budi. Bogor.

Andi, N.M. 2013. Pengaruh Level Ekstrak Daun Melinjo (Gnetum gnemon Linn) dan Lama Penyimpanan yang Berbeda Terhadap Kualitas Telur. Skripsi. Universitas Hasanuddin. Makasar.

Anggorodi, R. 1995. Nutrisi Aneka Ternak Unggas. PT. Gramedia Pustaka Utama. Jakarta. 
Ardika, I. N., N.W. Siti, N. M. S. Sukmawati, dan M. Wirapartha. 2017. Kualitas Fisik Telur Ayam Kampung yang Diberi Ransum Mengandung Probiotik. Majalah Ilmiah Peternakan. 20 (2) : 69:71.

Badan Standardisasi Nasional. 2008. Metode Pengujian Cemaran Mikroba dalam Daging, Telur, dan Susu, Serta Hasil Olahannya. SNI 2897:2008. Jakarta.

Campbell, N.A., Reece, J.B., \& Mitchell, L.G. (2003). Biologi. Jilid 2. Edisi Kelima. Alih Bahasa: Wasmen. Penerbit Erlangga. Jakarta.

Chung, TK. 2002. Yellow and red careotenoids for egg yolk pigmentations. 10th Annual ASA Southest Asian Feed Technology and Nutrition Workshop. Merlin Beach Resort. Phuket. Thailand.

Cooper, J.B. And W.E. Johnston. 1974. Albumen quality and shell thickness as affectedby time of egg gathering. Poult. Sci., $53: 1519-1521$.

Darmawati, D., Rukmiasih. dan R, Afnan. 2016. Daya tetas telur itik Cihateup dan Alabio. Jurnal Ilmu Produksi dan Teknologi Hasil Peternakan, Vol. 04 No. 1 Hal 257-263.

Dewi, G. A. M. K. 2010. Pengaruh Kalsium-Asam Lemak Sawit (Ca-ALS) dan Kalsium Terhadap Bobot Telur, Tebal Kerabang dan Kekuatan Kerabang Ayam Petelur Lohman. MIP. 13(1):20-35.

Djaelani,M.A. 2016. Kualitas telur ayam ras (gallus 1) setelah penyimpanan yang dilakukan pencelupan pada air mendidih dan air kapur sebelum penyimpanan. Buletin Anatomi dan Fisiologi . 24 (1) : 122-127.

Duman, M., A. Sekeroglu, A. Yildrum, H. Elerogu, and O. Camci. 2016. Relation between egg shape index and egg quality characteristic. European Poultry Science. 1-9.

Hafez, E.S.E. 2000. Reproduction in Farm Animals. 7 th ed. Lea \& Febiger, Philadelphia.

Hargitai, R., R. Mateo, J. Torok. 2011. Shell thickness and pore density in relation to shell colouration female characterstic, and enviroental factors in the collared flyctcher Ficedula albicollis. J. Ornithol. 152:579-588.

Haryono. 2000. Langkah-Langkah Teknis Uji Kualitas Telur Konsumsi Ayam Ras. Temu teknis Fungsional non Peneliti. Balai Penelitian Ternak. Bogor.

Hendrix Genetic Company. 2006. Layer Management Guide. Isa Brown, A Hendrix Genetic Company. Franc.

Jazil,N., A. Hintono dan S. Mulyani. 2013. Penurunan kualitas telur ayam ras dengan intensitas warna coklat kerabang berbeda selama penyimpanan. Jurnal Aplikasi Teknologi Pangan Vol. 2 No. 1.

Kunaifi, M. A., M. Wirapartha dan I K. A. Wiyana. 2019. Pengaruh Penyimpanan Selama 14 Hari Pada Suhu Kamar Terhadap Kualitas Eksternal dan Internal Telur Itik di Daerah Jimbaran. Peternakan Tropika. Denpasar. 
Kurniasih, D., Mohammad B. R., Catur R. H., \& Afif Z. A., 2017. Pembuatan Pakan Ternak dari Limbah Cangkang Kerang di Desa Bulak Kenjeran Surabaya, Seminar Master 2017PPNS, $159-163$.

Muharlien. 2010. Meningkatkan Kualitas Telur Melalui Penambahan Teh Hijau Dalam Pakan Ayam Petelur. Jurusan Produksi ternak. Fakultas peternakan. Universitas Brawijaya. Malang.

Nakajima, 1990. Re-Evaluasi of calcium and phosphorus requirement of laying hens for optimum performance and egg shell quality. Poult. Sci. 72 : 144- 153.

National Research Council (NRC). 1994. Nutrient Requirement Of Poultry, 9th Revised Edition. National Academy Press, Washington DC.

Oderkirk, A. 2001.The role of calcium phosphorus and vitamin D3 in egg shell and bone formation.Nova Scotia Department of Agriculture and Marketing.

Panda, P.C. 1996 Text Book on Egg and Poultry Technology. Vikas Publishing Haouse Pvt. Ldt., Hisar.

Scott, M.L., M.C. Nesheim and R. J. Young, 1982. Nutrition of the Chickens. Second Ed. M.L. Scott and Associates Ithaca,New York.

Standar Nasional Indonesia (SNI). 2008. Pakan ayam ras petelur (layer). Badan Standardisasi Nasional. Jakarta.

Steel, R. G. D. dan J. H. Torrie., 1989. Prinsip dan Prosedur Statistika. Suatu Pendekatan Biometrik, Edisi kedua. Diterjemahkan Oleh Sumantri. Gramedia, Jakarta.

Steward, G. F. and J. C. Abbott. 1972. Marketing Eggs and Poultry. Third Printing. Food and Agricultural Organization (FAO) the United Nation, Rome.

Sudaryani. 2003. Kualitas Telur. Penebar Swadaya. Jakarta.

Sumadi, I, K. 2017. Kebutuhan Mineral Pada Ayam Petelur. Penuntun Praktikum Ilmu Gizi Ternak Unggas Fakultas Peternakan Universitas Udayana.

Tugiyanti, E dan N. Iriyanti. 2012. Kualitas Eksternal Telur Ayam Petelur yang Mendapat Ransum dengan Penambahan Tepung Ikan Fermentasi Menggunakan Isolat Prosedur Antihistamin. Fakultas Peternakan Universitas Jendral Soedirman..

United States Department of Agriculture [USDA]. 2000. Egg Grading Manual. Agricultural Handbook, No. 75, Washington, D.C.

Wahju, J.. 1997. Ilmu Nutrisi Unggas. Cetakan ke-4. Yogyakarta: Universitas Gajah Mada Press.

Winarno, F. G. 2002. Kimia Pangan dan Gizi. Gramedia. Jakarta. 